\title{
EFFECTIVENESS OF COW DUNG COMPOST AND LIQUID ORGANIC FERTILIZER FRUIT FOR GROWTH AND PRODUCTION OF SHALLOTS
}

\author{
${ }^{1}$ Tharmizi hakim, ${ }^{2}$ Mei Lestari \\ ${ }^{1}$ Agrotechnology Study Program, Faculty of science and technology, \\ University Pembangunan Panca Budi, Medan-North Sumatera, Indonesia. \\ ${ }^{2}$ Graduated from Agrotechnology, Faculty of science and technology, \\ University Pembangunan Panca Budi, Medan-North Sumatera, Indonesia.
}

DOI: 10.46609/IJAER.2020.v06i02.007 URL: https://doi.org/10.46609/IJAER.2020.v06i02.007

\begin{abstract}
The demand for shallots increases every year, but the production of shallots decreases every year. The factor that influences the production of shallots is fertilization. Shallots need fertilizer and sufficient nutrients to increase growth and production. This research method uses factorial randomized block design (RBD) consisting of 2 factors, 16 combinations, and 2 replications. The first factor is cow manure compost with the symbol " $\mathrm{K}$ " consisting of 4 levels $\mathrm{K} 0=0 \mathrm{~g} /$ plot (control), $\mathrm{K} 1=1 \mathrm{~kg} /$ plot, $\mathrm{K} 2=2 \mathrm{~kg} /$ plot and $\mathrm{K} 3=3 \mathrm{~kg} /$ plot. Liquid organic fertilizer (LOF) fruits with the symbol "C" consist of 4 levels $\mathrm{C} 0=0 \mathrm{ml} / \mathrm{L}$ water / plot, $\mathrm{C} 1=250 \mathrm{ml} / \mathrm{L}$ water / plot, $\mathrm{C} 2=500 \mathrm{ml} / \mathrm{L}$ water / plot and C3 $=750 \mathrm{ml} / \mathrm{L}$ water / plot. The results showed that the administration of cow manure compost did not significantly affect the parameters of the number of leaves per sample, a number of tillers per sample, but significantly affected the production of wet tubers, dry tubers production, and conversion of shallots production, fruit LOF did not significantly affect all parameters namely number of leaves per sample (strands), a number of tillers per sample, wet tuber production per sample, dry tuber production per sample, conversion of shallots production.
\end{abstract}

Keywords: Compost of Cow Manure, Fruits Liquid Organic Fertilizer, shallots.

\section{INTRODUCTION}

Shallots are a highly repentant horticultural plant in people's lives, can be seen from its economic value and nutritional value. shallots tubers contain essential oils used as a delicious flavor 
International Journal of Agriculture and Environmental Research

ISSN: 2455-6939

Volume: 06, Issue: 02 "March-April 2020"

enhancer on food. It can also be sold in processed forms such as Gelatine shallots, fried shallots, and can also be used as a bactericide, traditional medicinal fungicide that can lower cholesterol, blood sugar, prevent blood clots, lower blood pressure, and facilitate blood. As a commodity of horticultural crops that are much needed in the community, the development of the potential of shallots is still very open both domestically and abroad (Suriani, 2012).

Recorded from the data of the National Central Statistics Agency (2018) the development of onion production in Indonesia in 2013-2017 fluctuated, caused by the increasing pattern of the shallots. Based on the average production of shallots in the period 2013-2017, there are four provinces in Central Java, East Java, West Java, and West Nusa Tenggara. The four provinces of the center accounted for $86 \%$ of Indonesian shallots production (BPS, 2018).

The demand for shallots is evenly distributed throughout the year, Adviesraad production depends on the pattern of planting. Where the successful shallots planting pattern is strongly influenced by the average amount of rainfall during the planting season, the production of shallots in the previous year, the area of the harvest of shallots in the year and the previous year. The growth and development of liquid processes are interconnected. Internal factors include genetic factors and specific individual physiological processes. While the external factors are liquid environmental factors affecting the growth of plants such as temperature, light, air, $\mathrm{pH}$, oxygen, and nutrients. To increase the nutrients needed by the shallot, one of the alternatives that can be done is to do fertilization (Nurjanah et al, 2017).

Fertilization is an effort made to increase the production of shallots. Previously, many farmers made fertilization by using inorganic fertilizers with continuous also with increasing doses. One of the organic fertilizer that can be used is compost. Liquid compost of macro and micronutrients, complete minerals in relatively small quantities $(\mathrm{N}, \mathrm{P}, \mathrm{K}, \mathrm{Ca}, \mathrm{Mg}, \mathrm{Zn}, \mathrm{Cu}, \mathrm{B}, \mathrm{Zn}$, $\mathrm{Mo}$, and $\mathrm{Si}$ ). In the long run, compost can increase the $\mathrm{pH}$ and increase crop yields. The Fender (CA) is a plant that is needed for cell renewal, stimulating the formation of root hair, and can neutralize the poisoned organic acids. Magnesium (Mg) serves to aid the transportation process of phosphate on crops and accelerates the formation of leaves. Sodium (Na) serves to increase plant growth when the plant is in the product question of potassium deficiency symptoms. Zinc (Zn) serves as vegetative growth and growth of seeds or fruit, forming analogs to grow. Nitrogen (N) serves to stimulate the overall growth, especially stems, leaves, the formation of green leaves. Proteins serve as bodybuilders. Phosphorus serves to stimulate the growth of roots, accelerate the flowering (Heri, 2011).

Liquid fertilizer is easy to set up and very useful for many things. It's liquid a good way to make rich fertilizers that will persuade nutrients from manure and other organic substances in small quantities. Liquid fertilizer can be easily melted on large areas of land. Liquid fertilizer is made 
in a solution of concentration so it needs to be mixed with air for its usage. Fertilizer can be stored anywhere, the origin of the permissible protected from the sun and rain. Liquid organic fertilizer that can be used can be obtained from the waste of vegetables, rotten fruits, and also can be derived from animal and human impurities (Sanad, 2008).

The waste is always identical to the deliberately discarded residual material whose novels are adverse to environmental and health impacts. Fruit waste derived from plantation and crops can be utilized as a fertilizer material. The organic fertilizer is liquid and compost. The fruits contain glucose and cellulose which can be used for this matter. The LOF of fermented products can be made from substrates containing carbohydrates (sugar, starch or cellulose) that can be produced through the process of biological fermentation (Ida, 2009).

\section{MATERIALS AND METHODS}

This research is conducted on the road Purwo Sunggal District of Deli Serdang Province North Sumatera, Indonesia with a height of area 30 meters above sea level. The material used in this research is the tuber shallots (Allium ascalonicum L.) Varieties of Bima Brebes, cow dung, straw rice, fruit (banana, pineapple, dragon fruit, oranges, and papaya), EM-4, brown sugar, coconut water, water, and paper labels. The tools used in this study are a hoe, tarp, meter, ruler, water barrel, blender, basin, bucket, knife, water sprinkler, camera, and stationery.

The method to be used in this study is to use a random draft group (RDG) factorial consisting of 2 treatments with 16 combinations of treatment with 2 repeats so that there are 32 research plots namely;

1. The factor I is the provision of compost fertilizer of cow dung $(\mathrm{K})$ consisting of 4 levels of administration, namely:

$$
\begin{aligned}
& \mathrm{K} 0=\text { Control } \\
& \mathrm{K} 1=1 \mathrm{~kg} / \text { plot } \\
& \mathrm{K} 2=2 \mathrm{~kg} / \text { plot } \\
& \mathrm{K} 3=3 \mathrm{~kg} / \text { plot }
\end{aligned}
$$

\section{Factor II is Fruit LOF (C)}

$$
\begin{aligned}
& \mathrm{C} 0=\text { Control } \\
& \mathrm{C} 1=250 \mathrm{ml} / \text { Liter of water/plot } \\
& \mathrm{C} 2=500 \mathrm{ml} / \text { Liter of water/plot } \\
& \mathrm{C} 3=750 \mathrm{ml} / \text { Liter of water } / \text { plot }
\end{aligned}
$$


3. Combination of 16 combination treatment.

$\begin{array}{llll}\text { K0C0 } & \text { K0C1 } & \text { K0C2 } & \text { K0C3 } \\ \text { K1C0 } & \text { K1C1 } & \text { K1C2 } & \text { K1C3 } \\ \text { K2C0 } & \text { K2C1 } & \text { K2C2 } & \text { K2C3 } \\ \text { K3C0 } & \text { K3C1 } & \text { K3C2 } & \text { K3C3 }\end{array}$

4. Number of Repeats

$(\mathrm{t}-1)(\mathrm{n}-1) \geq 15$

$(16-1)(\mathrm{n}-1) \geq 15$

$15(\mathrm{n}-1) \geq 15$

$15 \mathrm{n}-15 \geq 15$

$15 n \geq 15+15$

$\mathrm{n} \geq 30 / 15$

$\mathrm{n} \geq 2 \ldots \ldots .$. (2deuteronomy)

Data Analysis Methods;

1. Analysis of the observation data used is a variety analysis based on the linear model, namely the analysis model used in the analysis of the research data is:

$Y i j k=\mu+p i+\alpha j+\beta k+(\alpha \beta) j k+\varepsilon i j k$

Description:

Yijk = Results of the observation on the I block, the delivery of cow dung compost fertilizer and the provision of fruit LOF on the $\mathrm{K}$ level

$\mu \quad=$ Middle Value effect

pi $\quad=$ Block effect to-i

$\alpha \mathrm{j}=$ Cow manure compost effect

$\beta \mathrm{k}=$ Effect of giving fruit LOF at to-k level

$(\alpha \beta) \mathrm{jk}=$ Interaction between the factors of the provision of cow dung compost fertilizer at $-\mathrm{j}$ level and giving fruit LOF at a k-level

Eijk $=$ Error effect on the i-block, the giving of cow dung compost factor to the j-level and the factor of the fruit LOF to the k-level (Misbahudin, 2013).

2. The method of conversion analysis of the production of shallots plants used is the following formula: 
$\underline{\mathrm{Q}\left(\mathrm{m}^{2}\right)} \times \mathrm{H}(\mathrm{g})$

$\mathrm{L}\left(\mathrm{m}^{2}\right)$

Where:

$\mathrm{Q}=$ land area per ha $\left(\mathrm{m}^{2}\right)$

$\mathrm{H}=$ weight of bulbs per plot $(\mathrm{g})$

$\mathrm{H}=$ weight of bulbs per plot $(\mathrm{g})$

$\mathrm{L}=$ Area per plot $\left(\mathrm{m}^{2}\right)$ (Budianto et al, 2015).

\section{RESULTS AND DISCUSSIONS}

\section{Number of Leaves Per sample (strands)}

The research results after statistically analyzed Products that the compost delivery of cow dung and the fruit LOF is not real to the number of leaves. The vegetative phase against the compost of cow dung gives a good influence, although it does not give a striking effect. It is suspected. After all, low $\mathrm{N}$ elements are available on the ground because the $\mathrm{N}$ elements are easily lost and evaporated. This is in line with Fauzi and Mukhlis (2008). Element $\mathrm{N}$ is easily lost and becomes unprepared for crops. $\mathrm{N}$ unavailability in the soil can process the leaching through caused by rain that drops at the time of research, where NO-3 denitrification NO-3 to N2, volatilization of $\mathrm{NH} 4+$ to $\mathrm{NH} 3$, fixation by clay minerals or consumed by microorganisms in the soil. The increase in the number of leaves influenced by $\mathrm{N}$ elements is to help vegetative growth of plants, such as the formation of leaves, the formation of green leaves (chlorophyll) which is the place of photosynthesis, the more the number of leaves, the higher the chlorophyll content to accelerate the process of photosynthesis. If the $\mathrm{N}$ element available in the soil is insufficient so that the leaf growth is hindered. The addition of the number of leaves is a crop adaptation to the low level of sunlight received by the plant, it corresponds to (Hidayat, 2014) that $\mathrm{K}+$ in the cells inside the leaves affect the opening and closing the stomata, resulting in a photosynthetic process can take place so that the photosynthesis is needed by plants.

It is suspected that due to the time of giving the fruit LOF is done in Week 2 and 4th after planting or in the vegetative phase of the shallots plant. The 2-week time Interval is less than ideal in a LOF to plant because it causes the $\mathrm{N}$ levels available on the fruit LOF is quite low. Low absorption of element $\mathrm{N}$ from LOF fruits due to the loss of $\mathrm{N}$ on the fertilizer that is sprayed into the leaves, especially when the leaves do transpiration can not be absorbed by the plant with the maximum. According to Schorth and Sinclair (2003) in Jumini et al, (2012) The plant will acquire the nutrients in the optimum amount as well as the right time it will grow and develop to the fullest. Crop absorption is also influenced by the age of plants in this fertilization of plants 
International Journal of Agriculture and Environmental Research

ISSN: 2455-6939

Volume: 06, Issue: 02 "March-April 2020"

used in the studies is a short-lived plant. Results of research Parthasarathy et al. (2008) that with the increase of nutrient age nutrients $\mathrm{N}, \mathrm{P}$ and $\mathrm{K}$ nutrients will be higher.

\section{Number of tillers per sample (tubers)}

The results after statistically analyzed Products that the compost of cow dung and fruit LOF has no real impact on the number of saplings per sample. This is closely related to the number of leaves, the number of leaves associated with the capture of light and $\mathrm{CO} 2$ is more effective so that the rate of photosynthesis increases and affects the number of shallots (Elisabeth et al, 2013). Too low light intensity will limit photosynthesis and cause food reserves to tend to be more widely used than stored. The tiller will produce the tuber itself but at the beginning of its growth will use a food reserve of the old tuber (Haryanti, 2010).

The environment is defined as a set of all requirements (conditions) outside and provides an influence on crop growth and development. Extreme environmental conditions are high rainfall. The rainfall results in certain LOF fruit is lost because it is washed with rainwater (Ali et al, 2013). The properties of LOF are easily washed with rainwater and sun. Washing nutrients causes the absorption of nutrients that the plant requires does not run optimally, so the plant tends to only absorb nutrients in the soil. According to Joseph 1988 in Ega (2013) absorption mechanism through the leaves is less quality, because air availability is affected by temperature. Temperature is known to affect the growth of plants that affect the absorption of air. The rising temperature of the leaves greatly increases evaporation and slight diffusion but causes the stomata to close or open larger, depending on other factors. When the leaves are exposed to sunlight with heat exceeding the air temperature, the wind will lower the temperature, resulting in transpires decline. When groundwater content is limited, transpiration and $\mathrm{CO} 2$ absorption are hampered, because Stomata is closed as one way so that the plant does not lose much air. Rising temperatures make the air capable of carrying more moisture, the transpiration is increased generally environmental factors especially temperature, rainfall, and humidity affects the absorption of nutrients for the onion plants because it does not conform to the optimal environment so that it is not able to produce a mechanical result for shallots (Allium ascalonicum L.).

\section{Wet tubers Production Per Sample (g)}

The result of wet tubers per sample in table 1 states that the compost treatment of cow dung has a real effect on the production of wet bulbs per sample, namely in the K3 treatment of $24.61 \mathrm{~g}$.

The fruit LOF treatment has no real effect on the production of wet tubers per sample. The highest average result is the treatment of C3 24, $21 \mathrm{~g}$. 
Table 1: Wet tubers production rate per sample due to compost Cow dung and LOF at the age of 8 weeks after planting

\begin{tabular}{lc}
\hline Treatment & Wet tubers Production Per Sample $(\mathrm{g})$ \\
\hline Compost cow dung & \\
\hline $\mathrm{K} 0=0 \mathrm{Kg} / \mathrm{Plot}$ & $23,01 \mathrm{c}$ \\
$\mathrm{K} 1=1 \mathrm{Kg} / \mathrm{Plot}$ & $23,29 \mathrm{~b}$ \\
$\mathrm{~K} 2=2 \mathrm{Kg} / \mathrm{Plot}$ & $23,89 \mathrm{a}$ \\
$\mathrm{K} 3=3 \mathrm{Kg} / \mathrm{Plot}$ & $24,61 \mathrm{a}$ \\
\hline Fruit LOF & \\
\hline $\mathrm{C} 0=0 \mathrm{ml} / \mathrm{L}$ air/ Plot & $23,42 \mathrm{a}$ \\
$\mathrm{C} 1=250 \mathrm{ml} / \mathrm{L}$ air/ Plot & $23,42 \mathrm{a}$ \\
$\mathrm{C} 2=500 \mathrm{ml} / \mathrm{L}$ air/ Plot & $23,74 \mathrm{a}$ \\
$\mathrm{C} 3=750 \mathrm{ml} / \mathrm{L}$ air/Plot & $24,21 \mathrm{a}$ \\
\hline
\end{tabular}

Description: The numbers followed by the same letter in the same column show no distinct real at the $5 \%$ level in the test DMRT.

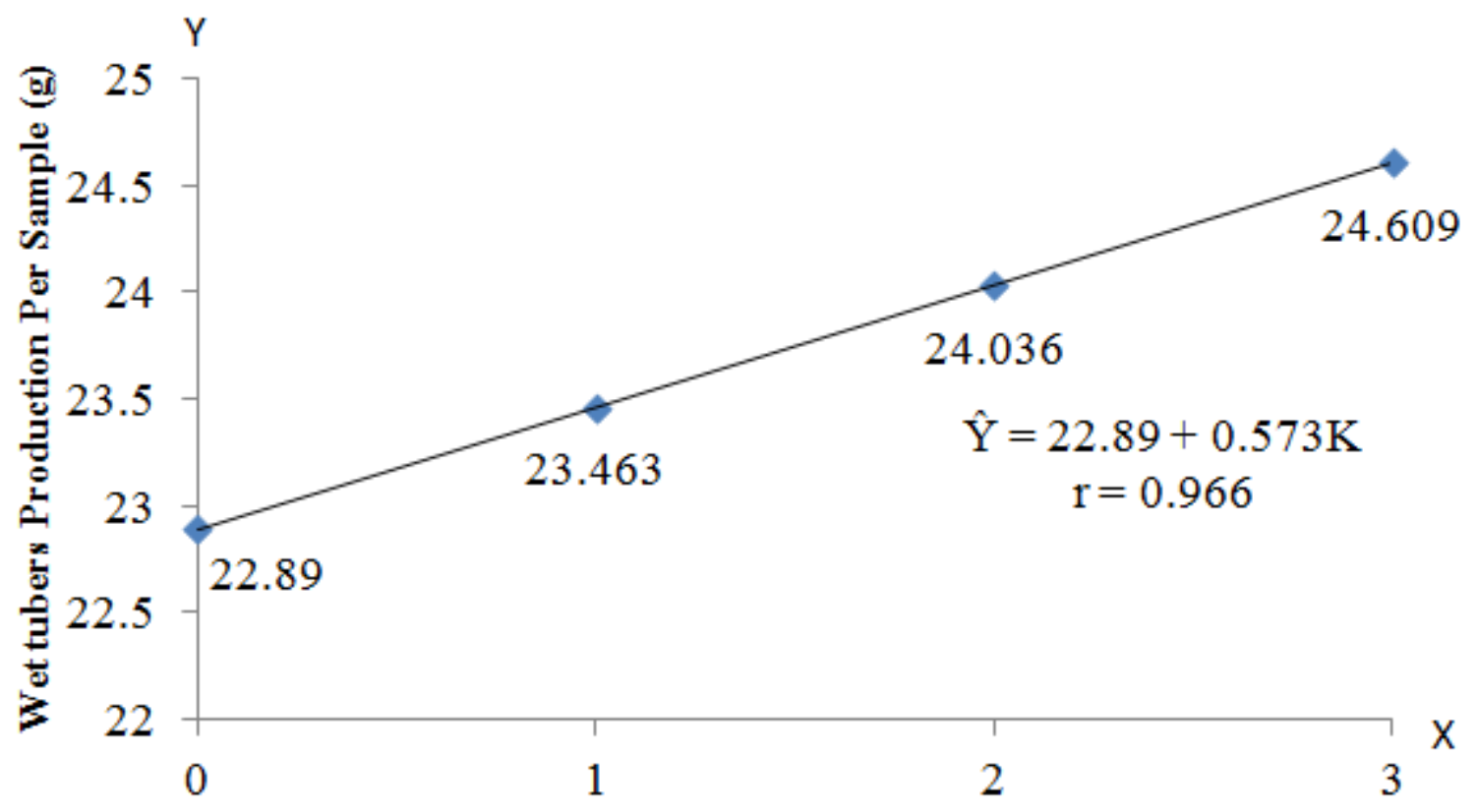

Compost cow dung

Graph 1: Relationship between the production of wet tubers per sample and feeding compost of cow dung 


\section{Dry Tubers production Per sample (g)}

Compost treatment of cow dung is a real effect on the production of dry tubers per sample. The DMRT 5\% level test indicates that the compost of cow dung is a real effect on the awarding dose of $3 \mathrm{~kg}$ per plot.

The fruit LOF is not tangible on the production of dry tubers per sample. The highest yield on the $\mathrm{C} 3$ treatment is $18.11 \mathrm{~g}$ and the result of the production of dried tubers per sample in $\mathrm{C} 0$ is $17.35 \mathrm{~g}$.

Table 2: Dry tubers production rate per sample due to compost Cow dung and fruit LOF on 1 week after harvest.

\begin{tabular}{lc}
\hline Treatment & Dry Tubers production Per sample $(\mathrm{g})$ \\
\hline Compost cow dung & \\
\hline $\mathrm{K} 0=0 \mathrm{Kg} /$ Plot & $17,32 \mathrm{c}$ \\
$\mathrm{K} 1=1 \mathrm{Kg} /$ Plot & $17,71 \mathrm{~b}$ \\
$\mathrm{~K} 2=2 \mathrm{Kg} /$ Plot & $17,87 \mathrm{a}$ \\
$\mathrm{K} 3=3 \mathrm{Kg} /$ Plot & $18,53 \mathrm{a}$ \\
\hline Fruit LOF & \\
\hline $\mathrm{C} 0=0 \mathrm{ml} / \mathrm{L}$ air/Plot & $17,35 \mathrm{a}$ \\
$\mathrm{C} 1=250 \mathrm{ml} / \mathrm{L}$ air/Plot & $18,01 \mathrm{a}$ \\
$\mathrm{C} 2=500 \mathrm{ml} / \mathrm{L}$ air/Plot & $17,96 \mathrm{a}$ \\
$\mathrm{C} 3=750 \mathrm{ml} / \mathrm{L}$ air/Plot & $18,11 \mathrm{a}$
\end{tabular}

Description: The numbers followed by the same letter in the same column show no distinct real at the $5 \%$ level in the test DMRT. 


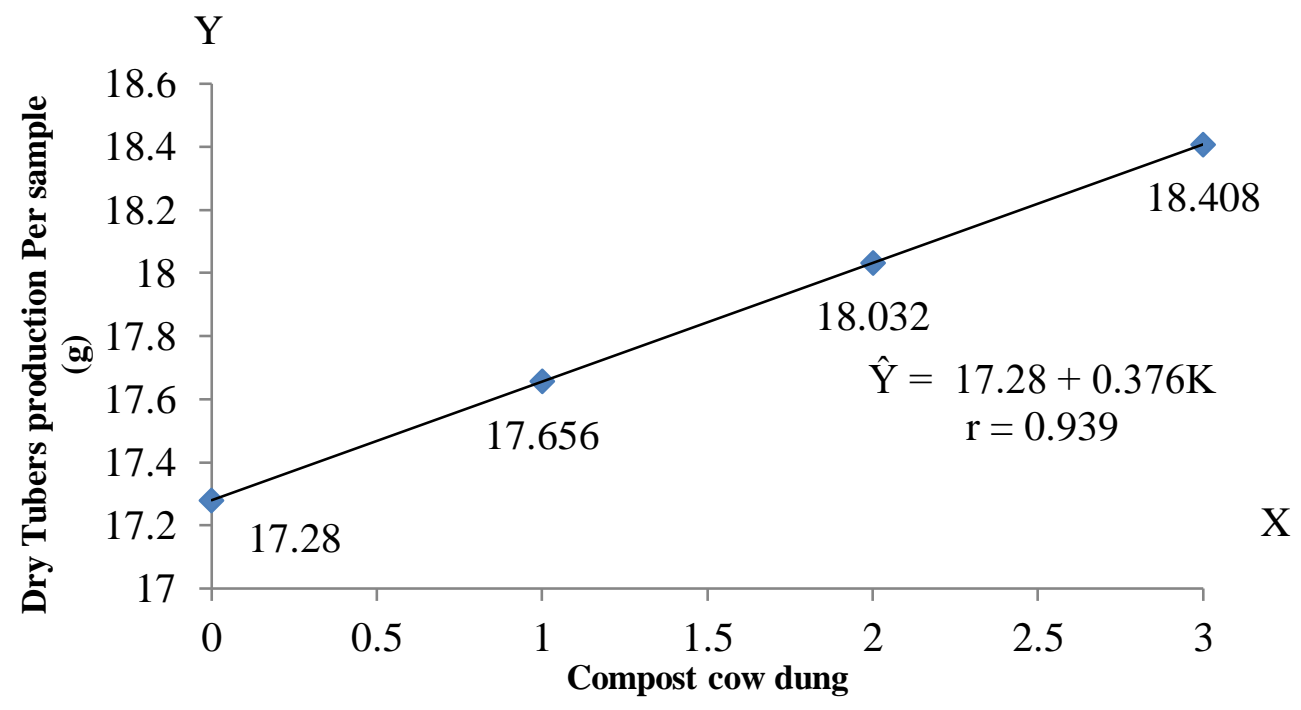

Graph 2: The relationship between dried tubers production per sample by providing compost of cow dung

\section{Production conversion per Ha (kg)}

Results of the average production of dry tubers per sample after the use of compost cow dung and fruit LOF after tested different average by using the test DMRT 5\%. The results in table 3 show that the compost treatment of cow dung is a real effect on the conversion of shallots production (Allium ascalonicum L.). The results of the conversion obtained above are still very low when compared with the results of the product obtained by farmers in general. On the fruit LOF in table 3 above, shows that an important fruit LOF is not noticeable on the conversion of shallots per ha production. The highest production rate at C3 treatment is $999.81 \mathrm{~kg} / \mathrm{ha}$.

Table 3: Production conversion rate per $\mathrm{Ha}(\mathrm{Kg})$ due to the compost of cow dung and fruit LOF 1 week after harvest

\begin{tabular}{lc}
\hline Treatment & Production conversion per Ha (kg) \\
\hline Compost cow dung & \\
\hline $\mathrm{K} 0=0 \mathrm{Kg} /$ Plot & $958,65 \mathrm{c}$ \\
$\mathrm{K} 1=1 \mathrm{Kg} /$ Plot & $977,25 \mathrm{~b}$ \\
$\mathrm{~K} 2=2 \mathrm{Kg} / \mathrm{Plot}$ & $990,13 \mathrm{a}$ \\
$\mathrm{K} 3=3 \mathrm{Kg} /$ Plot & $1007,13 \mathrm{a}$ \\
\hline Fruit LOF & \\
\hline $\mathrm{C} 0=0 \mathrm{ml} / \mathrm{L}$ air/Plot & $961,13 \mathrm{a}$
\end{tabular}



$\mathrm{C} 1=250 \mathrm{ml} / \mathrm{L}$ air $/$ Plot
987,44 a
$\mathrm{C} 2=500 \mathrm{ml} / \mathrm{L}$ air/Plot
984,69 a
$\mathrm{C} 3=750 \mathrm{ml} / \mathrm{L}$ air $/$ Plot
999,81 a

Description: The numbers followed by the same letter in the same column show no distinct real at the 5\% level in the test DMRT.

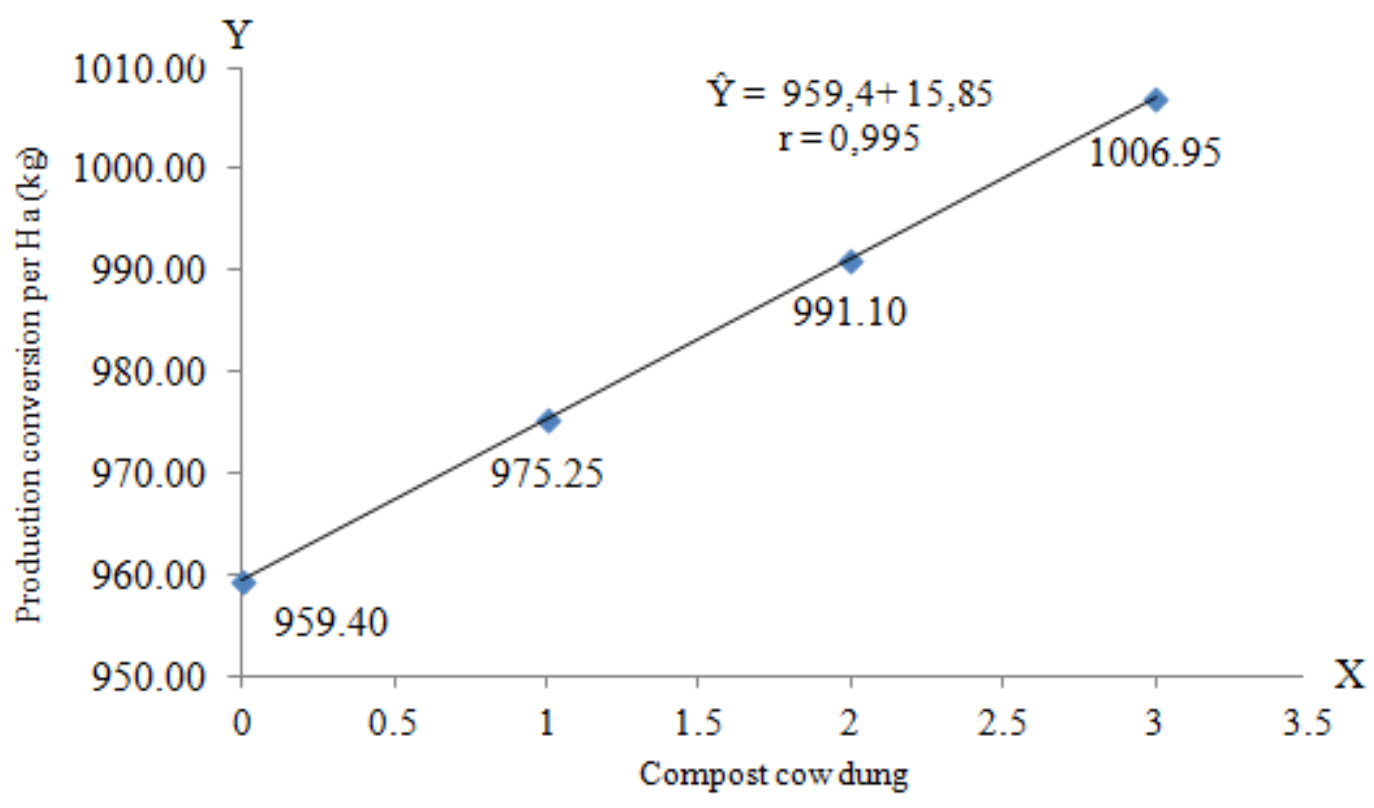

\section{Graph 3: Relationship between cow dung compost and fruit LOF with the conversion of shallots production per $\mathrm{Ha}(\mathrm{kg})$}

Judging from the above graph of cow dung compost gives a positive effect on the conversion of shallot production per ha, the linear regression equation is $\hat{Y}=959.4+15.85$, with $r=0.939$

\section{CONCLUSIONS}

The results of the research after being analyzed statistically that the compost is not real in the parameters of the number of leaves per sample on 3 and 5 weeks after planting (strands), the number of tillers per sample. The compost of cow dung is a real effect on the production parameters of wet tubers per sample $(\mathrm{g})$, the production of dry tubers per sample $(\mathrm{g})$, conversion of shallots production per ha $(\mathrm{kg})$. The best treatment in $\mathrm{K} 3$ is $3 \mathrm{~kg}$ of compost fertilizer with the highest average of $1007,13 \mathrm{~kg}$. 
International Journal of Agriculture and Environmental Research

ISSN: 2455-6939

Volume: 06, Issue: 02 "March-April 2020"

From the research results after being analyzed statistically that the delivery of the LOF fruit is not noticeable in all parameters of the number of leaves per sample on 3 and 5 weeks after planting (strands), the number of saplings per sample, the production of wet tubers per sample (g), the production of dry tubers per sample (g), and the conversion of shallots production per ha.

The interaction of cow compost gives the dirt and fruit LOF not seen in all parameters namely, the number of leaves per sample 3 and 5 weeks after planting (strands), several saplings per sample, the production of wet tubers per sample $(\mathrm{g})$, the production of dry tubers per sample $(\mathrm{g})$ and the conversion of plant production of shallots per ha $(\mathrm{g})$.

\section{ACKNOWLEDGMENTS}

Thank you to the Agrotechnology study program of the Faculty of Science and Technology and the Community Service Research Institute, Panca Budi Pembangunan University Medan Sumatera Utara, for their support so that this article can be published and editors and reviewers from the International Journal of Agriculture and Environmental Research.

\section{REFERENCES}

[1] Agus Budianto, Nirwan Sahiri, Ichwan S. Madauna. (2015). Effect of giving various doses of manure to growth and crop yield of shallots (Allium ascalonicum L) varieties of Palu Valley. Faculty of Agriculture, Tadulako University.

[2] Anjari Fadilla Nur Rahmadhani and Titin Sumarni. 2018. Shallots Plant Response ( allium ascalonicum L) against manure and an organic fertilizer (NPK). Journal of Crop production. Vol. 6. Malang.

[3] Anisyah, F., Rosita, S., and Chairani. 2014. Growth and production of shallots with the provision of various organic fertilizer. Agroteknologi Online Journal, 2 (2): 482-496.

[4] Ashari, S. 2009. Horticultural aspects cultivation. Publisher of Universitas Indonesia. Jakarta.

[5] Atyanta, Yohanes Tigana 2010. Quality of compost from the mixture of dairy dung and rice straw by using EM4 activator and Mol Tapai. Department of Production and Technology of livestock Faculty of Livestock Hussitut Bogor Ranch.

[6] Barus, J. 2011. Test the effectiveness of compost and NPK fertilizer against the yield of Padi. J. Agrivigor 10 (3): 247-252. 
International Journal of Agriculture and Environmental Research

ISSN: 2455-6939

Volume: 06, Issue: 02 "March-April 2020"

[7] Brewster, J.L. 2008. Onion and Other Vegetable Allium: Second Edition CAB. International New York. (US).

[8] BPS. 2018. Production of North Sumatera shallots. Bureau of North Sumatera Statistics. Medan.

[9] Damanik, MMBD., Hasibuan, BE., Fauzi,. Sarifuddin., and Haminah H. 2011. Soil fertility and fertilization. USU Press. Medan.

[10] Directorate General of Horticultural. 2008. Shallot seed production technology. Directorate of Perbenihan and production facilities. Results of cayenne pepper plants (capsicum Frutescens). Seminar Program of horticultural Semester V, State Polytechnic of Lampung, Lampung.

[11] Elisabeth, D.W., M. Santosa and N. Herlina. 2013. Effect of giving various compositions of organic matter on growth and yield of shallots (Allium ascalonicum L). Journal of Crop Production, 1 (3): 21-29.

[12] Fauzi and Mukhis. 2008. Soil chemistry theory and application. University of North Sumatera Press. Medan.

[13] Hadisuwito, S. 2009. Making liquid organic fertilizer. Agromedia Pustaka. Jakarta.

[14] Hannato, 2012. Influence of composting of organic waste as a material to manufacture fertilizer against the content of $\mathrm{C}, \mathrm{N}, \mathrm{P}$, and $\mathrm{K}$ in liquid organic fertilizer that is triggered. Thesis. Faculty of Mathematics and Natural Sciences, University of Gajah Mada, Yogyakarta.

[15] Healthy Aldriany P. and Leonardo L Sinaga, 2017. The response of type and dosage of organic fertilizer to growth and production of shallots (Allium ascalonicum L.) Agroteknoscience Journal | Vol. 01 | No. 01 | May 2017 | P-ISSN: 2598-6228 | E-ISSN: 2598-0092.

[16] Heri, M. 2011. Benefits and content of bananas. Yogyakarta: Earth Aksara.

[17] Hervani, D., Lili, S., Etti, S., and Erbasrida. 2008. shallots cultivation technology on some Media in the Pot in Padang city. The University of Andalas. Padang.

[18] Hidayat S, and Napitupulu, Rodame M. 2015. Book of Medicinal Herbs. Jakarta. A.

[19] Hidayat, A. 2014. Analysis of land development for peanut plant (Arachis hypogea L). In West Java. Journal of processing 1 (1); 46-50. 
International Journal of Agriculture and Environmental Research

ISSN: 2455-6939

Volume: 06, Issue: 02 "March-April 2020"

[20] Hony Kharisma Sejati, Murti Astiningrum, Tujiyanta, 2017. Influence of various manure and concentration of Pseudomonas fluorescens on shallots plant yield (Allium cepa fa. Ascalonicum L.) Veritas Crok yellow. Agrotechnology Study Program, Faculty of Agriculture, Tidar University. Journal of Tropical and Subtropical Agricultural Sciences 2 (2): $55-59$.

[21] Horticultural agriculture Office. 2018. Statistics of horticultural production in 2013. Jakarta: Directorate General of Horticultural Ministry of Agriculture.

[22] Implementing agency for agricultural extension, fisheries, forestry, and food security. (2016). Agritech: Vol. XVIII. No. 1. District of Banyumas.

[23] I Nyoman W.P., I Gusti B.W., and I Nyoman, S.W., 2011. Second-generation ethanol making use of Eucheuma cottonii seaweed waste as raw material. Bukit Jimbaran Bali Campus.

[24] Ida, R.E. 2009. Biomass as a bioethanol raw material. R \&amp; D Journal of Agriculture, No. 3 Vol. 28.

[25] Jumini, H.A.R. Hasinah, and Armis. 2012. Effect of time intervals of liquid organic fertilizer Enviro to the growth and outcome of two varieties of cucumber (Cucumis sativus L.) Floratek 7:133-140.

[26] Parthasarathy, V. A., B. Chemakam, and T. J. Zaehariah. 2008. Chemistry of Spices. $\mathrm{CAB}$ Internation. Printer and Bound in the UK by Biddles Ltd. Kings Lynn $445 \mathrm{p}$.

[27] Pranata, A.S. 2010. Liquid Organic fertilizer application and its benefits. Agromedia Pustaka, Jakarta.

[28] Ministry of Agriculture. 2014. Indonesian food material balance 2012-2013. Jakarta: Food Security Agency.

[29] Meryandini A, Widosari W, Maranatha B, Sunarti TC, Rachmania N, Satria H. 2009. The isolation of cellulolytic bacteria and its enzymatic characterization. Makara Sains, 13:3338.

[30] Moh. Ega Miska. 2013. Giving the effect of various types and doses of fertilizer Evagrow, Herbafarm, Bio Nautra against plants and the results of radish crops (Rahanus sativus var. hortensis L.). Thesis. Faculty of Agriculture, Jenderal Sudirman University. Purwokerto. 
International Journal of Agriculture and Environmental Research

ISSN: $2455-6939$

Volume: 06, Issue: 02 "March-April 2020"

[31] Tang, P. Y., C, J. Wong., K, K. Woo. 2011. Optimization of Pectin Extraction from Peel of Dragon Fruit (Hylocereuspolyrhizus). Asian Jurnal of Biological Sciences, 4(2): 189195. 